\title{
RESENHA
}

\section{A NEÓFITA GRIOT CONTADORA DE HISTÓRIAS CALU}

\author{
Régia Mabel da Silva Freitas?
}

\begin{abstract}
VALLE, Cássia; PALMEIRA, Luciana. Calu - uma menina cheia de histórias. Rio de Janeiro: Malê, 2017, 32 p., ISBN: 9788592736217.
\end{abstract}
"Museu, memória e imaginação são como um vulcão
Estão sempre em erupção, mobilizando a população Transformando as vidas...Isso é dinamização!"

$$
\text { (Calu - Rap da dinamização) }
$$

O livro infantil "Calu - uma menina cheia de histórias" é uma valiosa obra que contribui com maestria para o acervo da literatura infantil brasileira, que sobreleva uma educação antirracista. As suas autoras são as museólogas, historiadoras e coautoras do soteropolitano Projeto Patrimônio CIDADÃO, que visa à sensibilização para apropriar e preservar o patrimônio cultural afro-brasileiro, Cássia Valle (atriz e membro do Colegiado Gestor do Bando de Teatro Olodum) e Luciana Palmeira (coordenadora de acervos museológicos do Departamento de Processos Museais do Instituto Brasileiro de Museus).

1 Doutora em Difusão do Conhecimento (Universidade Federal da Bahia - UFBA). Pesquisadora, Palestrante e Organizadora de periódicos e eventos sobre Relações Raciais, Culturas Africana e Afro-brasileira e Teatro Negro brasileiro. Autora do livro "Bando de Teatro Olodum: uma política social in cena", capítulos de livros, artigos publicados em revistas nacionais e internacionais, resenhas, cordéis e poemas sobre as temáticas supracitadas. Coordenadora do NUMPERR (Núcleo Multidisciplinar de Pesquisa e Extensão em Relações Raciais) do Centro Universitário Ruy Barbosa - UniRuy. Membro do Núcleo de Pesquisas Afrobrasileiras em Artes, Tradições e Ensinagens na diáspora - ALDEIA - da Universidade Federal do Sul da Bahia (UFSB), Salvador, Bahia, Brasil. Orcid iD: http://orcid.org/0000-0002-6759-5251. E-mail:mabel_freitas@hotmail.com 
Publicado pela editora Malê, em 2017, foi prefaciado por Lázaro Ramos - ator, apresentador, cineasta, escritor de literatura infantil brasileira e embaixador da UNICEF (Fundo das Nações Unidas para as Crianças) -, que valorizou o conteúdo transformador pela representatividade do protagonismo e discurso negros. Ademais, o livro enalteceu coloridamente a beleza dos traços negroides pelo contorno militante da angolana estilista, designer, customizadora e ilustradora Maria Chantal, que ostenta a autoestima individual e coletiva da comunidade negra em seus trabalhos.

Lançado no mês considerado dos ibejis ${ }^{2}$ - outubro - de 2017, no Teatro Vila Velha, em Salvador, na Bahia, este livro é um presente de valor sóciohistórico-cultural para a construção da identidade étnico-racial de crianças negras, uma vez que compartilha com seus leitores uma comunidade azeviche sem estereotipia, estigmas e depreciação. As autoras - avessas a arquétipos seculares eurocêntricos - primam pela representatividade positiva que humaniza e qualifica cidadãos negros através de personagens que reconhecem, valorizam e disseminam a sua pluralidade cultural.

Calu, uma menina preta de seis anos, é neta dos griots ${ }^{3}$ Pedro e Dandara e irmã de Gabriel. Curiosa e cheia de imaginação, ela, que aprendeu com a mãe que os mais velhos por terem vivido bastante se tornam Mestre de Saberes, pedia sempre aos avós que the contassem histórias e as eternizava no seu bloquinho de colorir, registrando sua narrativa com ilustrações. Admirada pela sabedoria desses ascendentes, essa pretinha considerava mágica a ideia de viver muito. Afinal, como bem diz um provérbio africano, quando um velho morre perde-se uma biblioteca.

Interessada em saber sobre a ilha na qual moravam seus avós, pediu ao avô que the narrasse a história local. Ele contou, dirimiu suas inúmeras dúvidas e ainda a levou ao Museu da Cidade para que ela tivesse acesso e também observasse ainda mais informações in locus. Maravilhada com aquele "lugar bom para percorrer, ver, ouvir, perceber, entender, sentir, ouvir

\footnotetext{
${ }^{2}$ No candomblé, os ibejis são os orixás que representam as crianças; no sincretismo religioso, são associados aos gêmeos São Cosme e São Damião no panteão católico.

$3 \mathrm{Na}$ cultura africana, os griots são educadores que transmitem conhecimentos como músicos e contadores de história.
} 
e tocar" que despertou a relação identitária da infante com suas raízes ancestrais, ela teve uma brilhante ideia: procurar a prefeita para criar um museu itinerante na ilha na qual morava.

No bloquinho de colorir, delineou o planejamento que incluía exposição de fotos e áudio dos pescadores contando seus saberes e fazeres em sua Colônia, um acervo temporário na pracinha de fotos da Festa da Padroeira e do Samba das Marisqueiras, as deliciosas iguarias locais e os belíssimos artesanatos das sábias senhoras. Canonizando a riqueza da literatura oral herdada do continente africano, Calu diacronicamente dizia que "elas tinham aprendido com a vovó Dandara. Que ouviu da bisa, que havia aprendido com a tataravó e assim sucessivamente..."

Ciente da sabedoria ancestral aprendida no seio familiar, a pretinha protagonista escolheu Seu Marcus - um morador antigo do lugar - para recepcionar os visitantes que desejassem conhecer o legado do Museu da ilha Boca do Rio mostrando seus vários cantos, como a Casa de Pedra, embarcações, Colônia de pescadores e um espaço a céu aberto. Ele narraria a primeira história que explica o significado do nome e reverencia a mãe da água doce como uma heroína de negros aguerridos dos quilombos - os ancestrais dos moradores.

Para encerrar essa visita já repleta de cores, cheiros, sabores, a céu aberto, ela propõe que seja contemplada a beleza natural à noite ao som de um ritmo brasileiro de raízes africanas que é contagiante e traz muita alegria - o samba. Seu irmão Gabriel, aos dez anos, que já toca habilidosamente tambor, pandeiro e timbau - certamente, herança do vovô Pedro, o sambista mais antigo de lá - também contribuiria com esse momento de congraçamento. Assim, a celebração se daria num festivo encontro de gerações que dariam continuidade ao compartilhamento do legado.

Com a ajuda da magia dos querubins, esse bloquinho chegou até a mesa da prefeita que concretizou esse lindo sonho infantil, ratificando que a memória não pode nem deve permanecer em segredo, ela tem que ser revelada. No discurso inaugural, a prefeita louvou a inteligente criação dessa 
criativa garota que teve "a participação e o coração de toda a comunidade: pescadores, griots, marisqueiras, festeiras, sambistas, poetas, rezadeiras e seus mistérios, cozinheiras, rendeiras das mãos mágicas e crianças travessas cheias de alegria".

Com isso, as autoras, mais uma vez, exaltam a influência da cultura africana através da pluralidade de distintos saberes e fazeres de mestres da sabedoria para riqueza da historiografia local. O Rap da Dinamização da protagonista - trecho utilizado como epígrafe desta resenha - encerra a obra, retratando a cultura como um tesouro e o museu como um lugar de memórias no qual aprendemos quando vemos, ouvimos, saboreamos, cheiramos e tocamos. Essa epistemologia elucida que as aprendizagens se dão tanto pela dimensão física (enucleando todos os sentidos) quanto pela mental.

Há dois pontos da obra que merecem considerações disruptivas, a saber: a referência ao eurocêntrico querubim como o realizador de sonhos em detrimento da escolha de um ancestral africano como Exu (orixá da comunicação e abridor de caminhos) e a presença de alguns desvios de aspectos gramaticais. Vale ressaltar que esses itens supracitados não diminuem a qualidade teórico-conceitual da obra ora resenhada, entretanto é mister também trazê-los à baila.

Em tênue consonância com a Lei $n^{\circ} 11.645 / 08^{4}$, essa narrativa certamente contribuirá para uma educação antirracista dentro e fora do contexto escolar em meio ao ainda vigente eurocentrismo curricular nas mais distintas esferas formativas. Afinal, nesta sociedade lastreada por uma política ideológica que se alicerça nas fantasiosas fábulas das três raças e mito da democracia racial, urgem publicações didáticas e paradidáticas que oportunizem às crianças negras e não negras (re)conhecerem raízes e valorizarem sua ancestralidade para que tenham uma efetiva noção de pertencimento.

\footnotetext{
4 Lei, promulgada no governo do presidente Lula, que tornou obrigatório o Ensino da História e das Culturas Afro-Brasileira e Indígena nas escolas brasileiras públicas e privadas.
} 
Se nossas identidades devem ser desenvolvidas desde a mais tenra idade, cabe aos pais e educadores abolirem violências simbólicas repletas de visões negativas e caricaturais. Destarte, que mais obras antirracistas como esta - que apresenta características físicas e psicológicas de uma família preta com sensações, emoções e sentimentos salutares, nominando cada membro e resplandecendo o valor dos seus patrimônios material e imaterial - cintilem no ainda tão caucasiano universo da literatura infantil brasileira.

\section{Referências}

VALLE, Cássia; PALMEIRA, Luciana. Calu - uma menina cheia de histórias. Rio de Janeiro: Malê, 2017, 32 p., ISBN: 9788592736217

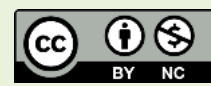

Recebida em: 10 de maio de 2020 Aprovada em: 29 de maio de 2020 Publicada em: 25 de julho de 2020 